\title{
Pelatihan Kerja Sebagai Sanksi Pidana Terhadap Anak Yang Berkonflik Dengan Hukum
}

\author{
Eka Rose Indrawati \\ Kejaksaan Negeri Sampang \\ ekarose.indrawati@gmail.com
}

\begin{abstract}
The legal issues raised in this study are job training as a criminal sanction against children in conflict with the law. This research is normative research with approach of legislation and concept approach. Based on the research that's been done form the criminal offence can be charged job training, as criminal sanctions against a child in conflict with the law, i.e. racing on the streets, reckless behavior, hooligans, messes that disrupt the tranquility of the surrounding environment, gang fights between groups, between schools, between tribes, so that sometimes bring casualties, skip school and stalk along the road or hide in remote places while conducting experiments of various crimes and immoral acts, child crime, adolescence threats, intimidation, blackmail, robbery, robbing, robbing, snatching, attacking, robbing, harassing, harassing, committing murder by slaughtering his victim, choking, poisoning, acts of violence, and other offenses, partying while drunk, free sex that disturbs the surroundings and rape against the women. The form of job training as a criminal sanction against children in conflict with the law can be in the form of general coaching which includes the eradication of three blind (illiterate, blind figures and language blind), mental spiritual form of religious education, personality, socio-culture: painting, dance art, sound art and musical arts, skill training in the form of sewing / crochet I sewing / cooking / weaving, workshop, scouting, youth training etc and recreation of sport, chess, entertainment and family visit.
\end{abstract}

\section{Keywords : Job Training, Criminal Sanction, Child, Conflict With The Law}

\begin{abstract}
Abstrak
Isu hukum yang diangkat dalam penelitian ini mengenai pelatihan kerja sebagai sanksi pidana terhada anak yang berkonflik dengan hukum. Penelitian ini adalah penelitian normatif dengan pendekatan perundang-undangan dan pendekatan konsep. Berdasarkan penelitian yang sudah dilakukan bentuk tindak pidana yang dapat dikenakan pemidanaan pelatihan kerja, sebagai sanksi pidana terhadap anak yang berkonflik dengan hukum, yaitu balapan di jalananan, perilaku ugal-ugalan, berandal, urakan yang mengacaukan ketentraman lingkungan sekitarnya, perkelahian antar geng, antar kelompok, antar sekolah, antar suku (tawuran), sehingga kadang-kadang membawa korban jiwa, membolos sekolah lalu bergelandang sepanjang jalan atau bersembunyi di tempat-tempat terpencil sambil melakukan eksperimen bermacam-macam kedurjanaan dan tindakan asusila, kriminalitas anak, remaja antara lain berupa perbuatan mengancam, intimidasi, memeras, mencuri, mencopet, merampas, menjambret, menyerang, merampok, menganggu, menggarong, melakukan pembunuhan
\end{abstract}


dengan jalan menyembelih korbannya, mencekik, meracun, tindak kekerasan, dan pelanggaran lainnya, Bentuk pelatihan kerja sebagai sanksi pidana terhadap anak yang berkonflik dengan hukum dapat berupa pembinaan umum yang meliputi pemberantasan buta aksara, buta angka dan buta bahasa, pendidikan mental spiritual berupa pendidikan agama, kepribadian/budi pekerti, sosial budaya: etika pergaulan, seni lukis, seni tari, seni suara dan seni karawitan, pelatihan keterampilan berupa kursus menjahit/merenda/menjahit/memasak/menganyam, perbengkelan, kepramukaan, pembinaan generasi muda dan sebagainya dan rekreasi olah raga, catur, hiburan dan kunjungan keluarga.

Kata Kunci : Pelatihan Kerja, Sanksi Pidana, Anak, Konflik Dengan Hukum

\section{Pendahuluan}

Indonesia sebagai negara hukum sebagaimana tertuang dalam Pasal 1 ayat 3 Undang - Undang Dasar Republik Indonesia Tahun 1945, memiliki konsekuensi logis bahwa segala tindak tanduk dari warga negara, pemerintah termasuk aparat penegak hukumnya harus berdasarkan hukum yang berlaku sehingga tidak ada ruang gerak bagi aparat negara untuk berbuat yang melanggar ketentuan hukum yang ada. Masyarakat pada umumnya kerap kali memahami hukum sebagai suatu perangkat aturan yang dibuat oleh negara dan mengikat warga negaranya dengan mekanisme keberadaan sanksi sebagai pemaksa. Tujuan hukum akan tercapai manakala terdapat keserasian antara kepastian hukum dengan kemanfaatan hukum sehingga menghasilkan suatu keadilan.

Penjatuhan pidana terhadap seseorang yang melakukan perbuatan pidana menjadi bagian yang sangat penting dalam mewujudkan sistem peradilan pidana yang baik, dalam hal ini hakim sudah seharusnya mampu memilih jenis pidana yang mana yang tepat dijatuhkan kepada pelaku. Oleh karena itu, peran hakim sangat menentukan efektifitas pemidanaan yang akan dijatuhkannya terhadap seorang pelaku. Dari sejumlah jenis hukuman yang ada di dalam Pasal 10 KUHP tersebut, hukuman penjara adalah salah satu jenis hukuman pokok yang sering menjadi pilihan bagi hakim dalam menjatuhkan hukuman bagi pelaku (Sugiharto, $2016: 2$ ).

Sanksi pidana yang ada di dalam Draf RUU KUHP tahun 2010 
mengalami beberapa perubahan, yakni seperti sanksi pidana menurut Draf RUU KUHP Tahun 2010 (Sugiharto, $2016: 3$ ) yaitu :

1) Pidana pokok yang terdiri atas :
a) Pidana penjara;
b) Pidana tutupan;
c) Pidana pengawasan;
d) Pidana denda;
e) Pidana kerja sosial.

2) Pidana tambahan yang terdiri atas :
a) Pencabutan hak-hak tertentu;
b) Perampasan barang tertentu dan/atau tagihan;
c) Pengumuman putusan hakim;
d) Pembayaran ganti kerugian;
e) Pemenuhan kewajiban adat setempat dan atau kewajiban menurut hukum yang hidup dalam masyarakat.

Jenis pidana yang terdapat di dalam draft RUU KUHP tersebut telah memasukkan pidana kerja sosial sebagai bagian dari jenis pidana pokok. Pidana kerja sosial cukup menarik untuk dikaji karena ini merupakan jenis pidana yang baru, yang jika disepakati akan menjadi salah satu pilihan jenis pidana yang diterapkan pada KUHP
Indonesia. Pidana kerja sosial merupakan salah satu jenis pidana pokok yang diatur pada Pasal 65 dan Pasal 86 RUU KUHP tahun 2010. Pada penjelasan kedua pasal tersebut dijelaskan, bahwa munculnya jenis pidana kerja sosial adalah sebagai alternatif pidana perampasan kemerdekaan jangka pendek dan denda yang dijatuhkan hakim kepada terdakwa dan perampasan kemerdekaan jangka pendek dalam hal ini adalah pidana penjara dan kurungan (Sugiharto, 2016 : 3).. Selain draf RUU KUHP yang telah memasukkan pidana kerja sosial sebagai bagian dari jenis pidana pokok, terdapat juga Undang Undang Nomor 11 Tahun 2012 tentang Pengadilan Anak yang mencantumkan Profesi Pekerja Sosial dalam menangani permasalahan anak yang berkonflik dengan hukum. Undang - Undang Nomor 11 Tahun 2012 telah ditetapkan dan diberlakukan pada tahun 2014. Undang - undang ini menyempurnakan undang-undang sebelumnya yaitu Undang - Undang Nomor 3 Tahun 1997 Tentang Pengadilan Anak. 
Pada Undang - Undang Nomor 11 Tahun 2012 mencantumkan Profesi Pekerja Sosial dalam menangani permasalahan anak yang berkonflik dengan hukum sehingga perlu adanya kajian yang mendalam mengenai profesi pekerja sosial agar semua profesi yang terlibat di dalamnya dapat harmonis dalam menjalankan tugasnya. Pada praktek pekerjaan sosial di Indonesia, anak bermasalah dengan hukum $(\mathrm{ABH})$ sudah menjadi permasalahan yang serius karena dari tahun ke tahun jumlahnya cukup tinggi. Jika hal ini terus dibiarkan, maka tentu hal ini tidak baik untuk perkembangan dan efektivitas anak.

Akhir-akhir ini perkembangan permasalahan anak di Indonesia semakin kompleks. Berdasarkan data yang diperoleh dari Ditjen Lembaga Pemasyarakatan, Departemen Hukum Dan HAM, populasi bekas narapidana dan bekas anak Negara sampai tahun 2003 tercatat sebanyak 115.307 orang. Dan diperkirakan dari tahun ke tahun jumlahnya semakin meningkat. Jika permasalahan ini tidak segera ditangani, dikhawatirkan akan menimbulkan masalah yang lebih kompleks (Sugiharto, 2016 : 3). Banyak anak-anak yang bersentuhan dengan hukum bahkan banyak pula yang sudah bermasalah dengan hukum. Anak yang berkonflik dengan hukum atau melakukan tindak pidana sesungguhnya karena keadaan atau kondisi obyektif yang melingkupi diri anak itu sendiri dan lingkungannya, seperti faktor kemiskinan menempati urutan tertinggi yaitu 29,35\% disusul oleh faktor lingkungan yaitu sebanyak $18.07 \%$, salah didik sebesar $11,3 \%$, keluarga tidak harmonis sebesar $8,9 \%$ dan minimnya pendidikan agama hanya 7,28\% (Sugiharto, $2016: 3)$.

Mengingat dampak negatif pidana perampasan kemerdekaan terhadap perkembangan anak yang berkonflik dengan hukum, maka Undang - Undang Nomor 11 Tahun 2012 Tentang Sistem Peradilan Pidana Anak yang mulai berlaku efektif pada tanggal 31 Juli 2014 sebagai pengganti Undang-Undang Nomor 3 Tahun 1997, menawarkan alternatif lain sebagai pengganti dijatuhkannya pidana perampasan 
kemerdekaan salah satunya adalah pidana pelatihan kerja. Namun pidana pelatihan kerja sebagai alternatif pidana perampasan kemerdekaan bagi anak yang berkonflik dengan hukum selama ini masih kurang efektif implementasinya.

Beranjak dari latar belakang permasalahan sebagaimana diuraikan di atas, maka dapat dirumuskan permasalahan sebagai berikut:

1) Tindak pidana yang dapat dikenakan pidana pelatihan kerja sebagai sanksi pidana tehadap anak yang berkonflik dengan hukum.?

2) Bentuk pelatihan kerja sebagai sanksi pidana terhadap anak yang berkonflik dengan hukum.?

\section{Pembahasan}

\section{Karakteristik Pelatihan Kerja} Sebagai Sanksi Pidana Terhadap Anak

Pemidanaan merupakan kegiatan yang dilakukan oleh hakim untuk menjatuhkan pidana terhadap pelaku tindak pidana supaya menimbulkan efek jera. Pemidanaan dapat diartikan sebagai tahap penetapan sanksi dan juga tahap pemberian sanksi dalam hukum pidana. Pada dasarnya pidana dijatuhkan supaya seseorang yang telah terbukti berbuat jahat tidak lagi berbuat jahat dan orang lain takut melakukan kejahatan serupa. Pemidanaan itu sama sekali bukan dimaksudkan sebagai upaya balas dendam melainkan sebagai upaya pembinaan bagi seorang narapidana sekaligus sebagai upaya preventif terhadap terjadinya kejahatan serupa.

Pidana penjara membawa pendidikan kejahatan oleh penjahat. Lembaga Pemasyarakatan (LAPAS) seringkali dijadikan sebagai tempat kuliahnya para penjahat yang akan melahirkan penjahat yang lebih profesional. Sanksi yang diberikan kepada pelaku juga memberikan efek negatif berupa dehumanisasi yaitu pengasingan dari masyarakat selama masyarakat kehilangan kemerdekaannya. Selain kurang efektifnya sanksi pidana yang diterapkan, ada faktor lain yang muncul dari pelaku yaitu tidak adanya rasa malu yang dimiliki oleh para pelaku stelah melakukan kejahatannya. 
Dewasa ini baik Indonesia maupun di dunia internasional muncul kecenderungan untuk mencari alternatif pidana perampasan kemerdekaan jangka pendek. Upaya untuk mencari alternatif pidana perampasan kemerdekaan bertolak dari kenyataan bahwa pidana perampasan kemerdekaan semakin tidak disukai baik pertimbangan kemanusiaan, pertimbangan filosofis, maupun pertimbangan ekonomis.

Beberapa dampak negatif pidana perampasan kemerdekaan adalah seseorang narapidana dapat kehilangan identitas diri akibat peraturan dan tata cara hidup Lembaga Pemasyarakatan, selama menjalani pidana narapidan selalu diawasi petugas sehingga ia kurang aman dan selalu merasa dicurigai atas tindakannya, sangat jelas kemerdekaan individualnya akan terampas hal ini menyebabkan perasaan tertekan sehingga dapat menghambat pembinaan dan lain sebagainya.

Restoratif Justice mengembalikan konflik kepada pihak-pihak yang paling terkena pengaruh seperti korban, pelaku dan kepentingan komunitas mereka dan memberikan keutamaan pada kepentingan-kepentingan mereka. Restoratif Justice juga menekankan pada hak asasi manusia dan kebutuhan untuk mengenali dampak dari ketidak adilan kerja dalam caracara yang sederhana untuk mengembalikan mereka daripada secara sederhana memberikan pelaku keadilan formal atau hukum dan korban tidak mendapatkan keadilan apapun (Septiano, $2014: 7$ ).

Sedangkan pidana pelatihan kerja yang akan dijatuhkan memenuhi unsur-unsur pembinaan dan memberikan perlindungan kepada masyarakat. Unsur pembinaan yang berorientasi pada individu pelaku tindak pidana. Dengan pidana pelatihan kerja terpidana terhindar dari dampak negatif seperti stigmatisasi, kehilangan rasa percaya diri sehingga terpidana memiliki kepercayaan diri yang sangat diperlukan dalam proses peminaan. Terpidana juga dapat menjalankan kehidupannya secara normal. Adanya kebebasan ini memberi kesempatan kepada terpidana untuk 
tetap menjalankan kewajiban kepada keluarganya. Terpidana juga dapat menghindari dari proses dehumanisasi dan secara otomatis dalam melakukan kerja dengan masyarakat.

Melihat konsep di atas, pelatihan kerja dalam sistem pemidanaan yang berasaskan teori tersebut wacana pidana pelatihan kerja perlu diterapka untuk para narapidana agar memicu munculnya rasa malu terhadap pelaku. Upaya ini layak ditempuh untuk membangkitkan sisi kemanusiaan para pelaku kejahatan dan memunculkan budaya malu serta rasa bersalah.

Pidana pelatihan kerja dijatuhkan secara kumulatif untuk pidana penjara yang lebih berat, setingkat kasus korupsi, kolusi, dan nepotisme, demi memberi rasa malu dan efek jera.

Lebih lanjut pidana Pelatihan kerja ini dilakukan secara rutin selama periode hukuman berlangsung. Hakim memvonis sekian bulan untuk menjalani pidana pelatihan kerja. Melalui pidana pelatihan kerja terpidana tidak akan berusaha untuk mengulangi kejahatan sebagaimana yang pernah dilakukan karena jika melakukan tindak pidana lagi, maka pengadilan akan menjatuhkan pidana penjara dan denda.

Ada beberapa negara di dunia yang telah menerapka pidana pelatihan kerja ini di dalam KUHPnya maupun dalam undang-undang kriminal lainnya. Biasanya negaranegara tersebut dalam menerapkan sanksi pidana pelatihan kerja itu sebagai alternatif pidana penjara jangka pendek dan pengganti pidana denda yang tidak dapat dibayar. Seperti negara Belanda, Polandia, Jerman, Inggris, Portugal, Denmark, dan lain sebagainya.

Lain halnya dengan Indonesia, jika di negara - negara eropa menerapkan pidana pelatihan kerja sebagai sanksi pidana yang dikenakan kepada anak nakal atau anak yang berkonflik dengan hukum, maka di Indonesia melakukan pembinaan. Pembinaan tersebut berupa pelatihan kerja. Adapun mengenai wujud pembinaan yang diberikan kepada anak yang berkonflik dengan hukum, yang meliputi pembinaan: 
a) Umum: pemberantasan tiga buta (buta aksara, buta angka dan buta bahasa).

b) Mental spiritual: pendidikan agama, PMP, kepribadian/ budi pekerti.

c) Kerja budaya: etika pergaulan, seni lukis, seni tari, seni suara dan seni karawitan.

d) Latihan ketrampilan: kursus menjahit/merenda/ menjahit/memasak/menganyam, kepramukaan, pembinaan generasi muda dan sebagainya.

e) Rekreasi: olah raga, catur, hiburan dan kunjungan keluarga.

Selanjutnya, berdasarkan ketentuan Pasal 69 Undang-Undang Nomor 11 Tahun 2012 Tentang Sistem Peradilan Pidana Anak, dinyatakan bahwa seorang anak dapat dijatuhi pidana setelah berumur 14 tahun, sedangkan anak yang belum berusia 14 tahun hanya dapat dikenai tindakan. Selanjutnya jenis pidana dan tindakan yang dapat dijatuhkan bagi anak nakal, yakni:

Dalam Pasal 71 UndangUndang No. 11 Tahun 2012 tentang
Sistem Peradilan Pidana Anak, anak dapat dijatuhi pidana sebagai berikut:

a) Pidana Pokok

1) pidana peringatan

2) pidana dengan syarat:

a) pembinaan di luar lembaga

b) pelayanan masyarakat, atau

c) pengawasan.

3) pelatihan kerja

4) pembinaan dalam lembaga, dan

5) penjara.

b) Pidana tambahan terdiri atas:

1) perampasan keuntungan yang diperoleh dari tindak pidana, atau

2) pemenuhan kewajiban adat.

Selanjutnya apabila dalam hukum materiil diancam pidana kumulatif berupa penjara dan denda, pidana denda diganti dengan pelatihan kerja. Pelaksanaan pidana yang dijatuhkan kepada Anak dilarang melanggar harkat dan martabat anak.

Lebih lanjut, tindakan yang dapat dijatuhkan kepada anak menurut Pasal 82 ayat (1) Undang- 
Undang Nomor 11 Tahun 2012

Tentang Sistem Peradilan Pidana

Anak, meliputi:

1) pengembalian kepada orang tua/Wali

2) penyerahan kepada seseorang

3) perawatan di rumah sakit jiwa

4) perawatan di LPKS

5) kewajiban mengikuti pendidikan formal dan/atau pelatihan yang diadakan oleh pemerintah atau badan swasta

6) pencabutan surat izin mengemudi; dan/atau

7) perbaikan akibat tindak pidana.

Pada umumnya terdapat empat macam kenakalan anak - anak (remaja) yaitu:

1) Delik kriminal yang dilakukan anak-anak (para remaja)

2) Delik lain yang tidak dicantumkan dalam peraturanperaturan yang berlaku bagi orang dewasa

3) Pre-deliquency atau pelanggaran terhadap norma educative

4) Anak-anak yang berada (in need of care and protection) atau memberikan ketentuan- ketentuan kesejahteraan anak (Septiano, 2014 : 7).

Lebih lanjut, gejala kenakalan anak (remaja) akan terungkap apabila kita meneliti bagaimana ciriciri yang amat menonjol pada tingkah laku dari anak tersebut, antara lain :

1) Rasa harga diri yang semakin menguat dan gengsi yang terlalu besar serta kebutuhan untuk memamerkan diri,

2) Energi yang berlimpah-limpah memanifestasikan diri dalam bentuk keberanian yang condong melebih-lebihkan kemampuan diri sendiri misalnya terefleksi pada kesukaan anak muda untuk kebut-kebutan di jalan raya.

3) Senang mencari perhatian dengan jalan menonjolkan diri, misalnya dengan jalan mabukmabukan minuman keras.

4) Corak hidupnya bercorak asosial dan keluar daripada dunia objektif kearah dunia subjektif sehingga ia tidak lagi suka pada kegunaan-kegunaan teknis yang sifatnya pragmatis melainkan 
lebih suka bergerombol dengan kawan sebaya.

5) Pencarian suatu identitas kedewasaan cenderung melepaskan diri dari identitas maupun identifikasi lama dan mencari keidealan dirinya sebagai identitas baru serta substitusi identifikasi yang lama (Septiano, $2014: 7$ ).

Hal tersebut dapat dimengerti dimana masa remaja merupakan masa transisi. Apabila tidak diiringi dengan tanpa adanya pembinaan dan pengawasan yang tepat dari semua pihak, anak gejala kenakalan ini akan menjadi tindakan - tindakan yang mengarah kepada tindakan yang bersifat kriminalitas.

Lebih tegas lagi dinyatakan oleh Adler yang dikutib oleh Tholib Setiady, yang menyatakan bahwa tingkah laku yang menjurus kepada masalah juvenile delinquency menurutnya adalah (Septiano, 2014 : 7) :

1) Kebut-kebutan di jalananan mengganggu keamanan lalu lintas yang membahayakan jiwa sendiri dan orang lain.
2) Perilaku ugal-ugalan, berandal, urakan yang mengacaukan ketentraman lingkungan sekitarnya. Tingkah laku ini bersumber pada kelebihan energi dan dorongan primitive yang tidak terkendali serta kesukaan menteror lingkungan.

3) Perkelahian antar geng, antar kelompok, antar sekolah, antar suku (tawuran), sehingga kadang-kadang membawa korban jiwa.

4) Membolos sekolah lalu bergelandang sepanjang jalan atau bersembunyi di tempattempat terpencil sambil melakukan eksperimen bermacam-macam kedurjanaan dan tindakan a-susila.

5) Kriminalitas anak, remaja dan adolesens antara lain berupa perbuatan mengancam, intimidasi, memeras, mencuri, mencopet, merampas, menjambret, menyerang, merampok, menganggu, menggarong, melakukan pembunuhan dengan jalan menyembelih korbannya, mencekik, meracun, tindak 
kekerasan, dan pelanggaran lainnya.

6) Berpesta pora sambil mabukmabukkan, melakukan hubungan seks bebas atau orgi (mabukmabukan yang menimbulkan keadaan kacau balau) yang menganggu sekitarnya.

7) Perkosaan

Kenakalan remaja dapat terjadi karena beberapa sebab yaitu karena ada motivasi dari remaja itu sendiri. Romli Atmasasmita, menyatakan bahwa motivasi dapat berbentuk motivasi intrinsik dan motivasi ekstrinsik. Motivasi intrinsik adalah dorongan atau keinginan pada diri seseorang yang tidak perlu disertai perangsang dari luar, sedangkan motivasi ektrinsik adalah dorongan yang datang dari luar diri seseorang (Atmasasmita, 2017 : 1). Yang termasuk motivasi intrinsik dari kenakalan remaja adalah faktor intelegensia, usia, kelamin, dan kedudukan anak dalam keluarga. Sedangkan motivasi ektrinsik dari kenakalan remaja adalah faktor keluarga, pendidikan dan sekolah, pergaulan anak, dan mass media.

\section{Bentuk Pelatihan Kerja Sebagai Sanksi Pidana Terhadap Anak Yang Berkonflik Dengan Hukum}

\author{
Berdasarkan Kitab Undang- \\ Undang Hukum Pidana (KUHP) \\ dikatakan bahwa semua anak, asal \\ jiwanya sehat dianggap mampu \\ bertanggungjawab dan dapat \\ dituntut. Ketentuan yang mengatur
} tentang anak yang melakukan tindak pidana harus mengacu pada ketentuan-ketentuan dalam Undang Undang Nomor 3 Tahun 1997. Undang - Undang Nomor 3 Tahun 1997 mengatur sanksi-sanksi yang dapat dikenakan terhadap anak sebagaimana ditentukan dalam Pasal 23 sebagai berikut:

(1) Pidana yang dapat dijatuhkan pada anak nakal ialah pidana pokok dan pidana tambahan.

(2) Pidana pokok yang dapat ditunjukan pada anak nakal ialah:
a) pidana penjara,
b) pidana kurungan,
c) pidana denda,
d) pidana pengawasan.

(3) selain pidana pokok sebagaimana dimaksud ayat (2) maka terdapat anak nakal dapat 
juga dijatuhkan pidana tambahan, berupa perampasan barang-barang tertentu dan atau pembayaran ganti rugi.

Konsep KUHP 2012 mengenai Pidana dan Tindakan bagi Anak diatur dalam Pasal 110 sampai dengan Pasal 128 Konsep KUHP 2012. Ketentuan tentang Pidana bagi anak diatur dalam Pasal 113 Konsep KUHP 2012 sebagai berikut:

(1) Pidana pokok bagi anak terdiri atas:

(a) Pidana verbal:

1) Pidana peringatan; atau

2) Pidana teguran keras.

(b)Pidana dengan syarat:

1) Pidana pembinaan di luar lembaga,

2) Pidana pelatihan kerja, atau

3) Pidana pengawasan,

(c) Pidana denda; atau

(d)Pidana pembatasan kebebasan:

1) Pidana pembinaan di dalam lembaga.

2) Pidana penjara, atau

3) Pidana tutupan
Berkaitan dengan ketentuan pidana yang memperhatikan kepentingan anak, pada tahun 2012 ini telah disahkan Undang-Undang Nomor 11 Tahun 2012 tentang Sistem Peradilan Pidana Anak (selanjutnya disingkat UndangUndang Sistem Peradilan Pidana Anak). Undang-Undang Sistem Peradilan Pidana Anak ini memperkenalkan jenis pidana yang lebih memperhatikan kepentingan anak, misalnya diperkenalkannya pidana peringatan, pidana pelayanan masyarakat, dan pidana pelatihan kerja. Berikut ini dipaparkan ketentuan pasal yang mengatur tentang sanksi pidana dalam Undang-Undang Sistem Peradilan Pidana Anak:

\section{Pasal 71}

(1) Pidana pokok terdiri atas:

a) Pidana peringatan.

b) Pidana dengan syarat:

1) Pembinaan di luar lembaga.

2) Pelayanan masyarakat.

3) Pengawasan.

c) Pelatihan kerja.

d) Pembinaan dalam lembaga, dan

e) Penjara. 
Pasal 78

(1) Pidana pelatihan kerja sebagaimana dimaksud dalam Pasal 71 ayat (1) huruf c dilaksanakandi lembaga yang melaksanakan pelatihan kerja yang sesuai dengan usia anak.

(2) Pidana pelatihan kerja sebagaimana dimaksud pada ayat (1) dikenakan paling singkat 3 (tiga) bulan dan paling lama 1 (satu) tahun.

Penjelasan Pasal 78 Ayat (1)

Yang dimaksud dengan "lembaga yang melaksanakan pelatihan kerja" antara lain balai latihan kerja, lembaga pendidikan vokasi yang dilaksanakan, misalnya, oleh kementerian yang menyelenggarakan urusan pemerintahan di bidang ketenagakerjaan, pendidikan, atau sosial.

\begin{tabular}{lrr}
\multicolumn{2}{c}{ Berkaitan dengan } & pidana \\
pelatihan kerja dalam & bentuk \\
melakukan & pelatihan & yang
\end{tabular}
bermanfaat untuk masyarakat guna menghukum atau sebagai pidana pengganti bagi anak yang berkonflik dengan hukum, maka diwujudkan melalui berbagai macam pelatihan kerja yang dijadikan hukuman bagi anak yang melakukan kejahatan seperti pelatihan ketrampilan berupa kursus menjahit/merenda/ menjahit/memasak/menganyam, perbengkelan, kepramukaan, pembinaan generasi muda dan sebagainya dan rekreasi olah raga, catur, hiburan dan kunjungan keluarga, bertugas di panti jompo, dan lain sebagainya.

Penerapan pidana pelatihan kerja sebaiknya diperluas. Bukan hanya sebagai hukuman pengganti untuk jenis tindak pidana ringan, pidana pelatihan kerja dapat diperluas sebagai hukuman kumulatif untuk jenis tindak pidana lebih berat Hukuman kumulatif berarti menggabungkan pidana penjara ditambah pelatihan kerja. Hal ini hakim jangan dibatasi untuk hanya memberlakukan pelatihan kerja sebagai pengganti pidana penjara kurang dari enam bulan. Dengan menambah hukuman pelatihan kerja pada pidana penjara, pelaku pidana atau publik dapat memperoleh efek jera lebih signifikan.

Pidana pelatihan kerja adalah bentuk pidana di mana pidana 
tersebut dijalani oleh terpidana di luar lembaga dengan melakukan pelatihanan kerja yang ditentukan. Lebih lanjut, dalam bahasan berikut ini, akan mengemukakan sampai seberapa jauh pidana pelatihan kerja dapat memenuhi tujuan dari pemidanaan itu sendiri. Pada Pembahasan yang ada dari berbagai tujuan pemidanaan merupakan bahasan yang sangat penting. Oleh karena itu, pembahasan dari berbagai teori tersebut akan mengantarkan pada permasalahan terhadap sejauh mana jenis pidana atau pidana pelatihan kerja relevan dalam sebuah sistem hukum pidana.

Dengan demikian dasar pembenar terhadap digunakannya satu jenis bentuk pemidanaan dalam suatu sistem hukum pidana yang berlaku yakni adalah tujuan pemidanaan yang seharusnya ditetapkan dalam sistem hukum pidana itu. Artinya sejauh mana tujuan pemidanaan yang ditetapkan itu dapat dipenuhi oleh pidana yang bersangkutan. Oleh karenanya untuk melihat apakah pemidanaan dalam bentuk pelatihan kerja relevan dengan sistem hukum pidana
Indonesia, akan terlihat sejauh mana pidana tersebut dapat memenuhi tujuan pemidanaan yang telah ditentukan.

Relevansi pelatihan kerja dengan aspek tujuan pemidanaan adalah sebagai berikut (Purwadiyanto, 2015 :162) :

a) Aspek perlindungan masyarakat. Pidana pelatihan kerja sebagaimana dimuka dijelaskan adalah merupakan alternatif pidana yang ditawarkan terutama untuk pidana perampasan kemerdekaan jangka pendek. Pidana pelatihan kerja diterapkan dengan syaratsyarat tertentu seperti tindak pidana yang dilakukan tidak terlalu berat, ada kesanggupan dari terpidana, dan sebagainya.

Sebagai alternatif pidana jangka pendek, pidana pelatihan kerja mempunyai berbagai keunggulan antara lain (Purwadiyanto, $2015: 162$ ) :

(1) Pidana pelatihan kerja sedikit banyak menisbikan proses stigmatisasi yang selalu menjadi efek pidana perampasan kemerdekaan. 
(2) Pidana pelatihan kerja akan meniadakan efek negatif berupa "pendidikan kejahatan oleh penjahat."

(3) Dilihat dari perspektif ekonomi, pidana pelatihan kerja juga jauh lebih murah dibanding dengan pidana perampasan kemerdekaan.

Menyadari sebagai keunggulan pidana pelatihan kerja sebagaimana tersebut di atas memberikan pemahaman bahwa pidana pelatihan kerja dengan demikian secara teoritis memberikan harapan besar untuk dapat lebih memberikan perlindungan kepada masyarakat akan bahaya kejahatan.

Dengan demikian pidana pelatihan kerja dapat memenuhi aspek tujuan pemidanaan yang berupa perlindungan masyarakat. Oleh karenanya, di lihat dari aspek perlindungan masyarakat pidana pelatihan kerja sebagai relevan dengan tujuan pemidanaan.

b) Aspek perlindungan individu Di lihat dari aspek perlindungan individu, agaknya pidana pelatihan kerja memberikan harapan besar sebagaimana suatu jenis pidana, lebih-lebih dengan falsafah pembinaan (treatment philosophy) yang sama berorientasi kepada individu pelaku tindak pidana. Dengan pidana pelatihan kerja seorang terpidana akan memperoleh berbagai keuntungan antara lain (Purwadiyanto, 2015 : 163) :

1) Terhindar dari berbagai penderitaan akibat perampasan kemerdekaan.

2) Dengan pidana pelatihan kerja terpidana tetap dapat menjalankan kehidupannya secara normal sebagaimana orang yang tidak sedang menjalani pidana.

3) Pidana pelatihan kerja dapat menghindari dehumanisasi" yang selalu menjadi efek negatif daripada pidana perampasan kemerdekaan.

Berhasilnya pembinaan individu terpidana di akan memberikan perlindungan kepada individu yang bersangkutan untuk tidak kembali 
melakukan tindak pidana. Namun, dilain pihak berhasilnya pembinaan terhadap individu terpidana juga memberikan perlindungan kepada masyarakat dari ancaman menjadi korban kejahatan. Dengan melihat dua aspek perlindungan tersebut di atas dan relevansinya dengan pidana pelatihan kerja maka pidana pelatihan kerja sebagai alternatif pidana yang ditawarkan sangat relevan dan sesuai dengan arah kebijakan internasional terhadap pemidanaan anak yang terlibat dalam hukum.

Jika pidana pelatihan kerja ini diharapkan dapat berfungsi maksimal sesuai dengan teori retributif, maka menurut hemat penulis jenis pidana ini tidak ditempatkan sebagai salah satu pidana pokok, tapi ditempatkan sebagai salah satu pidana tambahan. Dengan maksud dapat dijatuhkan bersama-sama dengan pidana pokok.

Sementara itu, yang berkaitan dengan anak yang berkonflik dengan hukum. Dalam ketentuan hukum di Indonesia, anak diartikan dalam beberapa istilah yakni orang yang belum dewasa, orang yang di bawah umur/ keadaan dibawah umur dan anak yang berada di bawah perwalian. Terkait dengan usia, beberapa aturan hukum mengatur ketentuan yang berbeda, penggunaan ketentuan tersebut berlaku asas preferensi hukum yaitu aturan yang sifatnya lebih khusus.

Menurut Marlina, anak adalah manusia yang belum mencapai 18 tahun termasuk anak yang masih dalam kandungan dan belum menikah (Marlina, 2012 : 33). Oleh karena itu, anak tidak dapat dikenakan pertanggungjawaban pidana secara penuh, karena seorang anak masih mempunyai keterbatasan kemampuan berfikir karena berada dalam pengawasan orangtua/walinya.

Dalam Pasal 1 angka 2 UndangUndang Nomor 11 tahun 2012 tentang Sistem Peradilan Pidana Anak dinyatakan anak yang berhadapan dengan hukum adalah anak yang berkonflik dengan hukum, anak yang menjadi korban tindak pidana, dan anak yang menjadi saksi tindak pidana. Hal ini dapat didefinisikan sebagai anak yang disangka, dituduh, atau diakui sebagai telah melanggar undang undang hukum pidana. Anak yang 
Berkonflik dengan Hukum sebagaimana yang diatur dalam Pasal 1 angka 3 Undang - Undang Nomor 11 tahun 2012 tentang Sistem Peradilan Pidana Anak. Dalam ketentuan tersebut dinyataan bahwa anak yang dapat dipertanggungjawabkan secara hukum jika anak telah berumur 12 (dua belas) tahun.

Anak pelaku tindak pidana hanya dijelaskan dalam Pasal 1 angka 3 Undang - Undang Nomor 11 tahun 2012 Tentang Sistem Peradilan Pidana Anak yaitu : “Anak yang berkonflik dengan hukum yang selanjutnya disebut anak adalah anak yang telah berumur 12 (dua belas) tahun, tetapi belum berumur 18 (delapan belas) tahun yang diduga melakukan tindak pidana". Anak yang berkedudukan sebagai pelaku disebut dengan anak yang berkonflik dengan hukum. Jika dilihat dari penjelasan tersebut, undang-undang mengisyaratkan tentang kemampuan anak dalam berkonflik dengan hukum adalah antara umur 12 tahun sampai dengan 18 tahun, hal ini dimungkinkan mengingat perkembangan emosi anak lebih stabil disbanding anak dibawah umur 12 (dua belas) tahun, akan tetapi peradilan pidana perlakuan terhadap anak tetap harus dibedakan dengan perlakuan orang dewasa.

Menurut Undang - Undang Nomor 11 tahun 2012 tentang Sistem Peradilan Pidana Anak, pelaku anak yang dapat dijatuhkan sanksi pidana (pidana pokok dan pidana tambahan) serta tindakan. Dengan menyimak pidana pokok pada Pasal 71 ayat (1) dan (2), maka pidana yang dapat dijatuhkan bagi anak yang berkonflik dengan hukum adalah (1) pidana peringatan; (2) pidana dengan syarat (pembinaan diluar lembaga, pelayanan masyarakat, atau pengawasan); (3) pelatihan kerja; (4) pembinaan dalam lembaga; dan (5) pidana penjara. Pidana tambahan yang dapat dijatuhkan terdiri atas (1) perampasan keuntungan yang diperoleh dari tindak pidana atau (2) pemenuhan kewajiban adat.

$$
\text { Undang - Undang Nomor } 11
$$
tahun 2012 tentang Sistem Peradilan Pidana Anak mengatur ketentuan yang relatif lain dari orang dewasa seperti yang ada pada UndangUndang Nomor 35 Tahun 2014 
tentang Perubahan Atas UndangUndang Nomor 23 Tahun 2002 Tentang Perlindungan Anak Pasal 77 sampai dengan Pasal 89 yaitu pidana penjara dan/atau denda, untuk pelaku anak pidana denda diganti dengan pelatihan kerja. Undang - undang menetapkan demikian sebagai ada upaya untuk mendidik anak yang bersangkutan agar memilki keterampilan yang bermanfaat bagi dirinya (penjelasan Pasal 78 ayat (1). Lama wajib pelatihan pelatihan sebagai pengganti denda, paling singkat 3 (tiga) bulan dan paling lama 1 (satu) tahun. Tentunya hal demikian mengingat pertumbuhan dan perkembangan fisik, mental, dan kerja anak serta perlindungan anak.

Untuk anak dibawah 14 tahun yang berhadapan dengan hukum hanya dikenakan dengan tindakan sebagaimana yang diatur dalam Pasal 69 Undang-Undang Nomor 11 tahun 2012 tentang Sistem Peradilan Pidana Anak. Beberapa tindakan yang dapat dijatuhkan kepada Anak yang berkonflik dengan hukum khususnya anak yang belum berusia 14 (empat belas) tahun dapat dilihat di Pasal 82 Undang - Undang Nomor
11 Tahun 2012 tentang Sistem Peradilan Pidana Anak meliputi

a) Mengembalikan kepada orang tua/wali;

b) Menyerahkan kepada seseorang;

c) Perawatan di rumah sakit jiwa;

d) Kewajiban mengikuti pendidikan formal dan/atau pelatihan yang diadakan oleh pemerintah atau badan swasta;

e) Pencabutan surat izin mengemudi; dan.atau

f) Perbaikan akibat tindak pidana.

\section{Simpulan}

Berdasarkan analisis yang dilakukan dapat disimpulkan bahwa bentuk tindak pidana yang dapat dikenakan pidana pelatihan kerja sebagai sanksi pidana terhadap anak yang berkonflik dengan hukum yaitu kebut-kebutan di jalanan, perilaku ugal-ugalan, berandal, urakan yang mengacaukan ketentraman lingkungan sekitarnya, perkelahian antar geng, antar kelompok, antar sekolah, antar suku (tawuran), membolos sekolah lalu bergelandang sepanjang jalan atau bersembunyi di tempat-tempat terpencil sambil melakukan eksperimen bermacam- 
macam kedurjanaan dan tindakan asusila, kriminalitas anak remaja antara lain berupa perbuatan mengancam, intimidasi, memeras, mencuri, mencopet, merampas, menjambret, menyerang, merampok, menganggu, menggarong, melakukan pembunuhan dengan jalan menyembelih korbannya, mencekik, meracun, tindak kekerasan, dan pelanggaran lainnya, berpesta pora sambil mabukmabukkan, melakukan hubungan seks bebas atau orgi (mabukmabukan yang menimbulkan keadaan kacau balau) yang menganggu sekitarnya dan perkosaan terhadap perempuan.

Bentuk pelatihan kerja sebagai sanksi pidana terhadap anak yang berkonflik dengan hukum dapat berupa pembinaan umum yang meliputi pemberantasan tiga buta (buta aksara, buta angka dan buta bahasa) dan pendidikan mental spiritual berupa pendidikan agama, kepribadian/budi pekerti, sosial budaya

\section{Daftar Pustaka}

\section{Buku}

Gosita, Arif. (2004) Masalah Korban Kejahatan. Jakarta: Bhuana Ilmu Populer
Gultom, Maidin. (2008) Perlindungan Hukum Terhadap Anak dalam Sistem Peradilan Pidana Anak di Indonesia. Bandung : Refika Aditama

Marlina. (2012) Peradilan Pidana Anak Di Indonesia, Pengembangan Konsep Diversi Dan Restorative Justice, Bandung : Refika Aditama

Marzuki, Peter Mahmud. (2005) Penelitian Hukum. Jakarta : Kencana Prenada Media Group

Muladi. (1995) Kapita Selekta Sistem Peradilan Pidana. Semarang : Penerbit Universitas Diponogoro

Prakoso, Abintoro. (2013) Pembaruan Sistem Peradilan Pidana Anak. Surabaya : Airlangga Press

Purwoleksono, Didik Endro. (2014) Hukum Pidana, Surabaya : Airlangga University Press (AUP)

Ruba'I, Masruchin dkk. (2015) Hukum Pidana. Malang : Media Nusa Creative 
Tongat. (2001) Pidana Kerja Sosial Dalam Pembaharuan Hukum Pidana Indonesia. Jakarta : Djambatan

Waluyo, Bambang. Viktimologi Perlindungan Korban dan Saksi, Jakarta : Sinar Grafika

Wibowo, Adhi. (2013) Perlindungan Hukum Korban Amuk Massa, Sebuah Tinjauan Viktimologi, Yogyakarta: Thafa Media

\section{Jurnal}

Achmad, Ruben, (2005) Upaya Penyelesaian Masalah Anak yang Berkonflik dengan Hukum di Kota Palembang, Jurnal Simbur Cahaya Nomor 27 Tahun $\mathrm{X}$

Gatot Sugiharto, (2016) Relevansi Kebijakan Penetapan Pidana Kerja Sosial Dalam Sistem Pemidanaan Di Indonesia, Jurnal Ilmu Hukum Novelty, Vol. 7 No.1 Februari

Rukmi, Shinta. (2008) "Prospek Pidana Kerja Sosial Di Indonesia", Wacana Hukum, Volume VII, No.1. April, Fakultas hukum Unsuri Surakarta.

Septiano, Muhammad Fajar. Pidana Kerja Sosial Sebagai Alternatif Pidana Penajara Jangka Pendek, Jurnal Universitas Brwijaya Malang
Sugiharto, Gatot. (2016) Relevansi Kebijakan Penetapan Pidana Kerja Sosial Dalam Sistem Pemidanaan Di Indonesia, (Jurnal Hukum Fakultas Hukum Universitas Ahmad Dahlan.

Taufan, Purwadiyanto. (2015) "Analisi Pidana Kerja Social Dalam Hukum Positif Di Indonesia”, Jurnal Lex Amsterdam, Vol.III/No.8/Oktober 